\title{
HIGH-SPEED RAIL SYSTEMS AND TOURISTS' DESTINATION CHOICE: THE CASE STUDIES OF PARIS AND MADRID
}

\author{
F. PAGLIARA ${ }^{1}$, M. DELAPLACE ${ }^{2} \&$ J. M. VASSALLO ${ }^{3}$ \\ ${ }^{1}$ Department of Civil, Architectural and Environmental Engineering, University of Naples Federico II, Italy. \\ ${ }^{2}$ Lab’Urba IFU - Université de Paris-Est, France. \\ ${ }^{3}$ Centre of Transport Invetigation (TRANSyT) - University of Madrid, Spain.
}

\begin{abstract}
The analysis of how tourists select their holiday destinations along with the factors determining their choices is very important for promoting tourism. In particular, transportation is supposed to have a great influence on the tourists' decisions. The aim of this paper is to investigate the role of High Speed Rail (HSR) systems with respect to a destination choice. Two key tourist destinations in Europe namely Paris, and Madrid, have been chosen to identify the factors influencing this choice. On the basis of two surveys to obtain information from tourists, it has been found that the presence of architectural sites, the quality of promotion of the destination itself, and cultural and social events have an impact while make a choice. However the availability of the HSR systems affects the choice of Paris and Madrid as tourist destinations in a different way. For Paris, TGV is considered a real transport mode alternative among tourists. On the other hand, Madrid is chosen by tourists irrespective of the presence of an efficient HSR network. Data collected from the two surveys have been used for a further quantitative analysis. Regression models have been specified and parameters have been calibrated to identify the factors influencing holidaymakers to revisit Paris and Madrid and visit other tourist places accessible by HSR from these capitals. Keywords: High-speed rail, Madrid, Paris, tourism.
\end{abstract}

\section{INTRODUCTION}

High Speed Rail (HSR) systems represent the present and the future of transport investments. Indeed many projects have been recently carried out all around the world [1].

The European Commission foresees that, by the year 2050, medium distance transport of passengers will take place by train including HSR [2].

The objective of this research is to analyse how tourism destination choice may be affected by HSR Services (HSRS). Although there is some research works on the relationship between HSR and tourism [3, for a review], the objective of this paper has been barely analysed. For this reason it seems interesting to know how holidaymakers select and revisit their holiday destinations, and to investigate which factors are determining their choices. Moreover, an increase in tourism demand brings an increase in employment and, in turn, a significant contribution to the GDP of a country.

This paper is organised as follows. Section 2 provides an overview of the literature on the interactions between HSR and tourism. This section highlights the factors influencing the choice and the role of HSR systems on it. Section 3 describes the case studies of Madrid and Paris, and shows the results of the surveys conducted in each city. In Section 4, on the basis of the results from the surveys, two models are calibrated: the first model simulates the probability of revisiting Madrid and Paris and the impact of HSR on this choice. In the second model, the probability of choosing HSR as a transport mode for visiting cities located nearby is investigated. Finally in Section 5 the conclusions of this research and further perspectives are reported.

\section{AN OVERVIEW OF PREVIOUS STUDIES ON THE LINK BETWEEN HSR AND TOURISM}

The analysis on how urban tourism destination choice may be affected by HSRs needs to identify the elements affecting the choice of destination and the role played by transport and more specifically by HSRs.

(C) 2015 WIT Press, www.witpress.com

ISSN: 1743-7601 (paper format), ISSN: 1743-761X (online), http://journals.witpress.com DOI: 10.2495/SDP-V10-N3-399-410 


\subsection{The determinants of destination choice}

As quoted by Rugg [4] 'little theoretical or empirical research has been generated on the determinants of the demand for foreign travel'. From a microeconomic point of view, the existing tourism demand literature is dominated by econometric models, which follow a single-equation time-series approach [5], and from few advanced studies of demand systems [6]. Because the existing demand models do not consider measures of traveller's attitudes including perceptions of service attributes and personal feelings toward different destinations and/or services, they are not sensitive to the wide range of strategies that can be designed to motivate, influence, or change consumer travel behaviour [7]. In addition to the most popular time series models, Song and $\mathrm{Li}$ [8] reported an overview of the modelling and forecasting methods that can be applied to tourism revisiting a location. Logistic regression models have been extensively used also for tourist demand analysis $[9,10]$ as a means to explain the decision to go or not to go on holiday. Very interesting are some contributions analyzing the relationship between past experiences and the perceived image of a tourist destination [11,12]; individual characteristics and the type of accommodation used [13]; duration of the holiday, socio-demographic motivations, and destination characteristics [14].

\subsection{HSR and tourism}

Despite the fact that the literature acknowledges the fact that transport is very important for the development of tourism, the analysis of its role in destination choice has often been underestimated [15] even though 'the health of the nation's tourism industry is inextricably tied to the efficiency of its transport system' [16]. Indeed, transport is intrinsically linked to tourists' behaviour. According to gravitation models [17] the number of visitors that can be attracted to a destination depends on the magnitude of the population in a market area and on the distance between this destination and this market area. The number of tourists decreases with growing distance.

In this respect, a transport innovation such as HSR - modifies the link between tourists and distance because a decrease of travelling time in the end means a decrease of distance. HSR can decrease generalised transport costs with the consequence that users are expected to have a greater willingness to pay for HSR.

Masson and Petiot [18] stated that the introduction of HSR can improve tourists' utility and reinforce the attractiveness of a certain region for them, and also the competition between destinations. Some cities can take advantage of HSR while others might be disadvantaged [19].

Significant contributions in the literature [20-24] show that the effects are first ambivalent and second depending on the cities. In some served cities, the number of tourists is growing, sometimes for a short duration, but in other places the number of nights spent in the city can decrease.

In a research concerning Spain, Coronado et al. [25] show that the effect of HSR on same-day tourism is linked to the improvement of the accessibility and the tourist offers. Chen and Haynes showed that China's provinces served by HSRs 'are likely to have approximate 20 percent additional numbers of foreign arrivals and 25 percent greater tourism revenues than provinces without such systems' [26]. For these authors, HSR will have an effect on the strengthening of the competitiveness in tourism.

HSR can improve the tourism market in the destination because it affects tourists' perception of this destination: local stakeholders used it to improve the city image [27-29].

\subsection{The intention to revisit a given destination}

Another interesting aspect for tourism is to identify the reasons explaining tourists' intention to revisit a specific destination. In this respect, HSR might be one of the reasons why tourists 
choose to revisit a certain city or region. Very few contributions in this respect are present in the literature. One paper analyses the probability of revisiting Cyprus related to socio-demographic and destination characteristics [30]. In this paper a micro-econometric approach, based on observations of holidaymakers, is proposed. This approach allows the examination of the characteristics that influence individual travel behaviour and provides a conceptual/methodological framework for the understanding of the nature, form and character of the holiday-decisionmaking processes of individuals. Another research work analyses the variables influencing the probability of revisiting Lisbon by using a mixed logit model and a mixed logit with bounded parameters. The probability of revisiting Lisbon 'increases significantly with accommodation range, events, food quality, expected weather, beach, overall quality, nightlife, reputation, and safety' [31]. The authors also show that the overall quality and reputation variables, which are not statistically significant in the logit model, become statistically significant in the mixed logit model.

There are few contributions evaluating the link between HSR and 1) tourism destination choice and 2) tourism intention to revisit a destination. As mentioned above, there is a gap in the literature concerning the relationship between tourism and transport, and HSR in particular. Furthermore, only few studies used a quantitative approach for this analysis.

\section{THE CASE STUDIES OF PARIS AND MADRID}

In this section the case studies of Madrid and Paris are described. First, the two HSR networks of Spain and France are defined. After that the main results of the survey are summarised.

The first HSR link in France, the South East HSR between Paris and Lyon, was opened in 1981 while in Spain the section Madrid-Cordoba-Seville $470 \mathrm{~km}$ long was inaugurated in 1992. The two HSR networks, as they were at the time this paper was written, are shown in Fig. 1.

The sample was chosen randomly among tourists visiting these two cities. In Paris, the survey was conducted from October 26 to November 2, 2012 (7.45 a.m. to 7.00 p.m.) in three locations: the Eiffel Tower, Notre Dame Cathedral, and Paris Lyon Central Train Station.

In Madrid, the survey was conducted from June 24 to June 28, 2013 (10.00 a.m. to 2.00 p.m./4.00 p.m. to 7.00 p.m.). The locations chosen were four popular touristic places: the Royal Palace, Mayor Square, Prado Museum, and Reina Sofia Museum [33].

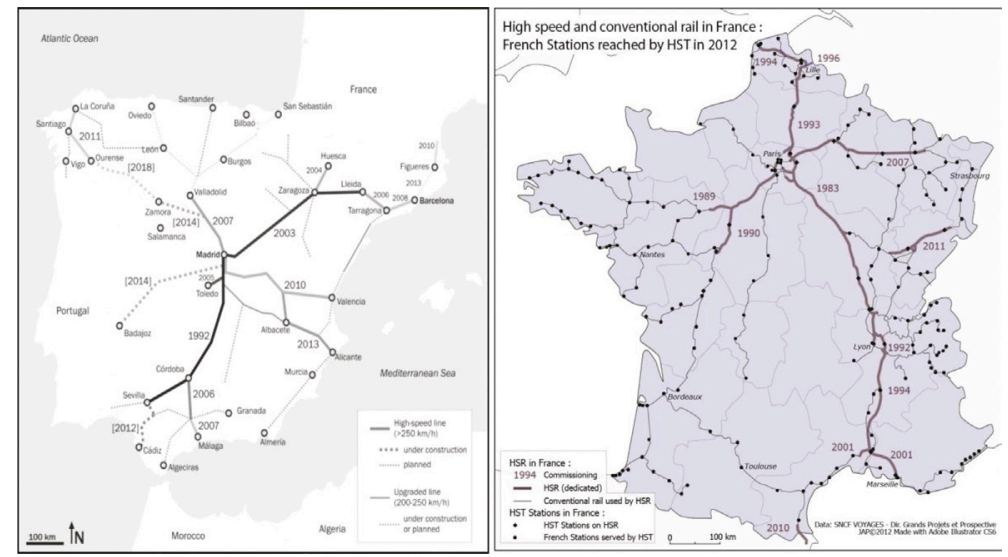

Figure 1: HSR systems in Spain (on the left) and in France (on the right) [32]. 
The two questionnaires submitted are very similar in their content, but the population surveyed was greater in Madrid (501 respondents) than in Paris (226). Five differences between the two surveys are worth mentioning. First, in Madrid the percentage of men surveyed was higher than in Paris. Second, the sample in Paris was more partnered than the one in Madrid. Third, the percentage of foreigners was greater in Madrid than in Paris. Fourth, in Madrid there were more employees and fewer managers than in Paris. And five, the income per capita of tourist was lower in Madrid than in Paris, which might be a consequence of the previous difference.

Concerning the transport modes used to arrive in Madrid (see Table 1), the most common ones were the airplane $(59.1 \%)$, HSR (12.8\%), and car (11.0\%). A lower percentage chose the coach, partial HSR (on the same section the train can be HSR as well), and intercity rail (respectively 9\%, $4 \%$, and $4 \%$ ). For obvious reasons, the airplane was used mostly by foreigners. Only $8.6 \%$ of the Spanish tourists chose the plane to get to Madrid, 28\% arrived in Madrid by HSR, $28 \%$ by car, and $18 \%$ by coach. Foreign tourists arrived mostly by plane (78.5\%) due to their constraints to choose another mode of transport. Only $6.9 \%$ of them reached the city by HSR.

The length of the trip (including departure from home, arrival in Madrid, travel to other cities, overnight stay, and return home) was on average 14 days. Moreover, 5 days is the average duration of the stay in Madrid. The average budget estimated for the whole trip in Spain was $2150 €$ (see Table 2).

The average length of the trip in the French case study was 7 days whereas the average duration of stay in Paris was, like Madrid, 5 days. About the budget estimated for the whole trip in France, it was an average of $1050 €$, from less than $50 €$ to $12,000 €$ (based on 178 respondents).

In the survey, tourists were asked about their main motivations to visit the cities of Paris and Madrid. In the case of Paris, HSR was the third main motivation after cultural offers (83\%) and historical and architectural landmarks (81\%). Gastronomy (47\%), presence of relatives in the Parisian area (46\%), and personal events (42\%) were also important motivations for visiting Paris, but they were not as important as the presence of HSR. French tourists were more sensitive to HSR

Table 1: Transport modes to reach Madrid and Paris.

\begin{tabular}{lccccc}
\hline & \multicolumn{2}{c}{ All sample } & & \multicolumn{2}{c}{ Foreign tourists } \\
\cline { 2 - 3 } \cline { 5 - 6 } Transport modes & Madrid & Paris & & Madrid & Paris \\
\hline HSR & $12.80 \%$ & $49.00 \%$ & & $6.90 \%$ & $\underline{38.00 \%}$ \\
Plane & $59.10 \%$ & $34.00 \%$ & & $78.50 \%$ & $52.00 \%$ \\
Car & $11.00 \%$ & $15.00 \%$ & & $4.40 \%$ & $10.00 \%$ \\
Train & $8.00 \%$ & $2.00 \%$ & & $4.40 \%$ & $0.00 \%$ \\
Coach & $9.00 \%$ & $0.00 \%$ & & $5.80 \%$ & $1.00 \%$ \\
\hline
\end{tabular}

Table 2: Length of the stay.

\begin{tabular}{lcc}
\hline Travel information & Madrid & Paris \\
\hline Total travel days & 14 & 7 \\
Days in the capital & 5 & 5 \\
Average budget $(€)$ & 2150 & 1050 \\
\hline
\end{tabular}


services in choosing that destination $(60 \%)$. Also, $75 \%$ of the respondents influenced by TGV services actually used HSR to get to Paris. The convenience (23\%), due to the level of service, and the existence of the service (19\%) had a strong influence for not choosing HSR. A notable percentage of respondents in Madrid (41\%) were positively influenced by the presence of HSR in their destination choice, especially because of the HSR speed $(66 \%)$, the possibility to visit other cities linked by HSR (13\%), and the accessibility of the departure/arrival stations (7\%). A large percentage of respondents in Paris (49\%) were positively influenced by the presence of HSR, especially because of the travel speed (94\%), but also by the good accessibility of both departure (75\%) and destination stations $(72 \%)$. Frequency of the service $(56 \%)$ and the reduction of travel time $(51 \%)$ were also important motivations (see Table 3).

Tourists were also asked about their willingness to revisit the city where they were surveyed (either Madrid or Paris). A large amount of the tourists (78\%) were willing to revisit Madrid for another holiday (see Table 4). They were mainly foreigners (53\%), using airplanes (77\% of foreigners). Forty eight per cent of those who intended to return to Madrid were driven by the richness of the historical, artistic, monumental heritage, and cultural events (see Table 4). On the other hand, tourists that have already visited all the attractions in Madrid (43\%), and tourists whose home country was far away (37.3\%) were less willing to come back. Concerning the case study of Paris, $98 \%$ of the respondents wished to revisit this destination. Both French (99\%) and foreign tourists (97\%) wished to come back. This percentage was high, irrespective of the mode of transport used to get to Paris (98\% of the tourists who came by HSR wished to return). Their motivations were mostly linked to their wish to discover more $(40 \%)$ and the attractiveness of the destination (36\%). Having relatives in Paris was also a strong motivation (27\%).

3.1 Impact of HSR on tourists visiting other cities connected by this service

As part of the survey, tourists were asked about the influence that HSR had on them to visit locations close to the city where they were surveyed. In Madrid there were a high percentage of respondents

Table 3: Influence of HSR on the choice of destination.

\begin{tabular}{lcc}
\hline Influence of HSR & Madrid (\%) & Paris (\%) \\
\hline Yes & 41.10 & 49.00 \\
No & 58.90 & 51.00 \\
Motivations & Madrid (\%) & Paris* (\%) \\
Less travel time & 65.80 & 94.00 \\
Accessibility of the departure/arrival station & 7.00 & 75.00 \\
Frequency of service & 0.50 & 56.00 \\
Less costly & 3.50 & - \\
Visiting other cities linked by HSR & 12.10 & - \\
Safety & 0.50 & - \\
Environmentally friendly & 1.50 & - \\
Comfort & 8.50 & - \\
Other & 0.50 & - \\
\hline
\end{tabular}

*In the case of Paris, tourists could choose more than one alternative so the total is not equal to 100 . 
Table 4: Aspects that influence positively the willingness of tourists to revisit Madrid (\% of the survey).

\begin{tabular}{lclc}
\hline Motivation to revisit Madrid & $\%$ & Motivation to revisit Paris & $\%$ \\
Relatives/Friends & 28.4 & Relatives/Friends & 27.0 \\
$\begin{array}{l}\text { Historical and Architectural land- } \\
\text { marks/Museum }\end{array}$ & 47.8 & Attractiveness of destination & 36.0 \\
National culture/Gastronomy & 12.5 & To discover more & 40.0 \\
$\begin{array}{l}\text { Less costly than other destination } \\
\text { Good quality of tourism promotion }\end{array}$ & 1.5 & Tourist supply & 20.0 \\
Shopping and general events (sport, & 6.3 & & \\
music, etc.) & 6.1 & & \\
HSR & 0.0 & & \\
Other & 1.3 & & \\
\hline
\end{tabular}

Table 5: Visiting cities other than Madrid and Paris.

\begin{tabular}{lcc}
\hline Tourists visiting other cities nearby & Madrid $(\%)$ & Paris $(\%)$ \\
\hline Yes & 62.10 & 20.00 \\
No & 37.90 & 80.00 \\
National & 10.00 & 49.00 \\
Foreigner & 90.00 & 61.00 \\
Tourists using HSR to visit other cities & Madrid (\%) & Paris $(\%)$ \\
Yes & 56.00 & 53.00 \\
No & 44.00 & 47.00 \\
\hline
\end{tabular}

(62.1\%), most of them foreigners, who actually visited other places. Fifty six per cent of them used HSR to visit nearby cities. The tourists choosing HSR to visit other locations in the country did it because of the travel time savings ( $73.6 \%$ of the sample using HSR to visit nearby cities). On the other hand, the main motivation for not using HSR to visit other cities near Madrid was the high price of the ticket (34\% of the sample did not use HSR to visit nearby cities), and the absence of a HSR line between Madrid and the chosen destination (51\% of the sample did not use HSR to visit nearby cities).

In the case of Paris, $20 \%$ of the respondents visited another place during their trip. Forty three per cent of them were influenced by the TGV services for visiting others places, and 53\% were actually using it. In several cases, they were not able to reach it by TGV (too far, etc.). For those respondents visiting other destinations, $61 \%$ were foreigners but they were less sensitive than French tourists to HSRs.

\section{MODELLING THE PROBABILITY OF REVISITING PARIS AND MADRID AND OF VISITING CITIES CLOSE TO PARIS AND MADRID BY HSR}

4.1 The probability to revisit Paris and Madrid: very different results

A further quantitative analysis has been carried out. Regression models have been specified and calibrated to identify the factors influencing holidaymakers to revisit Madrid and Paris. 
The literature on logistic regression is large and has been growing since 1970, especially in social sciences and educational research. These models have been extensively applied also for the analysis of tourist demand [10], especially to explain the decision to do/not to do a holiday. In this research, the probability of revisiting the city has been specified according to a very simple linear regression model.

The type of tourists that most likely would revisit Madrid and Paris is analysed, given their socioeconomic, tourist and transport related attributes. The dependent variable is the willingness to revisit Madrid or Paris (Yes: 1, No: 0), the independent variables are dummy variables. Estimates are reported in Table 6.

In the case of Madrid, the model presents a high explanatory power indicating that the regression fits the sample data quite well. All the parameters are highly significant except TRANSP_COST>700 and the HSR variable, which are not significant, even though they have the expected sign. Being satisfied by past experiences (FIRST_TIME_MADRID) has a positive impact on the probability to revisit Madrid. Indeed those people who already visited Madrid have a higher chance of returning. With reference to the socioeconomic characteristics, Spaniards have a higher probability to revisit Madrid for tourism purpose because Madrid is more accessible to domestic tourists than to foreigners.

HSR and transportation costs do not seem to have a big impact on the destination choice. Indeed, although the transportation cost has the correct sign, it is not significant. Nevertheless, the quality of promotion of the heritage resources is important. The main outcome from the Madrid case study is that tourists will revisit the capital irrespective of the presence of HSR.

In the case of Paris, all the attributes are significant and have the expected sign. Tourists that are willing to revisit Paris are younger than the average (aged between 18 and 24) and they are French.

Table 6: Variables influencing the probability of revisiting Madrid and Paris.

\begin{tabular}{|c|c|c|}
\hline & Madrid & Paris \\
\hline Variable & Coefficient (t-test) & Coefficient (t-test) \\
\hline AGE_18-24 & - & $0.105(1.979)$ \\
\hline MARRIED & $-0.063(-2.315)$ & - \\
\hline FREELANCE & $0.104(2.2040)$ & - \\
\hline NATION & $0.121(3.633)$ & $0.192(3.904)$ \\
\hline UNIV & - & $0.238(5.111)$ \\
\hline FIRST_TIME_MADRID & $-0.083(-2.809)$ & - \\
\hline STAY_RELAT_HOME & $0.111(2.131)$ & - \\
\hline TRAV_FRIENDS & - & $0.167(3.063)$ \\
\hline HSR & $-0.015(-0.552)^{*}$ & $0.177(4.167)$ \\
\hline TRANSP_COST $>700 €$ & $-0.028(-0.954) *$ & - \\
\hline VISIT_RELAT & - & $0.160(3.416)$ \\
\hline ARCHITECT & $-0.559(20.409)$ & $0.434(9.712)$ \\
\hline MULTI_DEST & - & $0.172(3.677)$ \\
\hline EVENT & - & $0.0902(2.036)$ \\
\hline $\mathrm{Rho}^{2}$ & 0.493 & 0.650 \\
\hline Rho $^{2}$ adj & 0.485 & 0.595 \\
\hline
\end{tabular}

*Not significant. 
They travel with friends, and they would like to get back to Paris because of its architectural sites, the opportunity of visiting other places from there, and the possibility of visiting relatives. Paris is also a city full of events, and this is a factor influencing the choice to be back. The HSR variable is very significant and positive, meaning that for young people the presence of HSR influences their choice. The variable itself embeds all the characteristics connected with HSRs, i.e. high speed, reduction of travel times, high frequency, reliability, easy access to the station, and so on. Moreover young people are aware of the reduced fares from which they can benefit.

4.2 Modelling the probability of visiting cities close to Paris and Madrid by HSR

The second model aims at identifying the variables having an impact on the choice of HSR to travel from Madrid or Paris to nearby cities served by HSR. Dummy variables have been considered and the estimation results are reported in Table 7.

In the case of Madrid, all the attributes have the expected sign and are significant: easy access to nearby cities by AVE (EASY_2NEARCITIES), the accessibility of departure/arrival station (STATION_ACCESS), travel comfort (COMFORT), service frequency (SERV_FREQ), and safety (SAFETY) have a positive impact on the probability of choosing HSR to visit cities located nearby. The cost of transportation (TICKET_COST) has a negative impact. Foreign tourists are using HSR more frequently than the Spanish ones for visiting cities close to Madrid by HSR. This is confirmed by the negative sign of the variable NATION.

In the case of Paris, the tourist who has the highest probability of visiting cities close to Paris by HSR is French with an income below $€ 2500$ per month, willing to stay in Paris less than 5 days out of a trip 7 days long. TGV will be chosen because of the easy access to two nearby cities connected by it. The total cost for the holiday is less than $€ 1000$.

Consequently the role of HSR in the probability of visiting other cities is different in Madrid compared to Paris.

Table 7: Variables influencing the probability of visiting cities close to Madrid and Paris by HSR.

\begin{tabular}{lcc}
\hline & \multicolumn{2}{l}{ Madrid } \\
\cline { 2 - 3 } Variable & Coefficient (t-test) & Coefficient (t-test) \\
\hline NATION & $-0.140(-2.249)$ & $0.108(2.417)$ \\
INCOME_0-2500Euro & - & $0.084(1.954)$ \\
TOT_HOLID_7days & - & $-0.425(-7.443)$ \\
STAY_PARIS_5days & - & $0.238(4.589)$ \\
TOT_HOLID_COST & - & $-0.257(-2.792)$ \\
EASY_2NEARCITIES & $0.296(5.101)$ & $0.289(5.822)$ \\
SAFETY & $0.273(4.547)$ & - \\
SERV_FREQ & $0.328(4.317)$ & - \\
TICKET_COST & $-0.359(-6.921)$ & - \\
COMFORT & $0.456(10.658)$ & - \\
STATION_ACCESS & $0.398(7.419)$ & 0.41 \\
$\rho 2$ & 0.631 & 0.392 \\
$\rho^{2}$ adj & 0.594 & \\
\hline
\end{tabular}




\section{CONCLUSIONS AND FURTHER PERSPECTIVES}

The objective of this paper was to investigate the factors influencing the choice of a destination or tourism purpose in order to identify the role of HSR in this choice. The literature review shows that HSR can positively affect tourism for several reasons (e.g. accessibility, growth of the competiveness, etc.). The research shows that even though several factors influence the choice of a tourist, like the presence of architectural sites, the quality of promotion of the destination itself, the presence of events, etc., the HSR system also plays a role in this choice, but in a different way in the two case studies. In France, HSR has a significant influence on the probability of revisiting Paris, while in Madrid this behaviour has not been confirmed by the analysis. There are some reasons explaining this difference. The first one is that most of the tourists in Madrid are foreigners, who cannot use HSR to get to Madrid; whereas in Paris most of the tourists are French or from nearby countries. The second one is that Paris is a touristic attraction by itself, while Madrid is the 'arrival point' to visit many places in Spain. For this reason, the analysis suggests that foreign tourists in Madrid choose HSR for visiting cities close to Madrid. Even though this research sheds light in the understanding of HSR and tourism, further investigation is still necessary to better know the specific role of HSR in other countries and, inside the same countries, in other cities, especially the intermediate ones.

The findings provide useful information for analysts in their efforts to target specific tourist segments and to identify the way HSR can impact tourism. Awareness of tourists' characteristics with respect to a specific destination represents an important input for improving packaging and promotion. In this respect, the implementation of more sophisticated and wide ranging surveys taking into consideration other relevant and transport related dimensions at the regional, national and international level would be of greatest interest for future research.

\section{REFERENCES}

[1] UIC (International Union of Railways), High Speed Lines in the World, available at http://www.uic.org/IMG/pdf/20120701_a1_high_speed_lines_in_the_world.pdf (accessed 1 November 2013).

[2] EC White Paper, Roadmap to a single European transport area-towards a competitive and resource efficient transport system, 2011.

[3] Bazin, S., Beckerich, C., Blanquart, C., Delaplace, M. \& Vandenbossche, L., Grande vitesse ferroviaire et développement économique local: une revue de la littérature. Recherche, Transports et Sécurité, 27(106), pp. 215-238, 2011. doi: http://dx.doi.org/10.1007/s13547-0110016-2

[4] Rugg, D., The choice of journey destination: a theoretical and empirical analysis. The Review of Economics and Statistics, 55(1), pp. 64-72, 1973. doi: http://dx.doi.org/10.2307/1927995

[5] Lim, C., Review of international tourism demand models. Annals of Tourism Research, 24(4), pp. 835-849, 1997. doi: http://dx.doi.org/10.1016/s0160-7383(97)00049-2

[6] O'Hagan, J.W. \& d Harrison, M.J., Market shares of US tourist expenditure in Europe: an econometric analysis. Applied Economics, 16, pp. 919-993, 1984. doi: http://dx.doi. org/10.1080/00036848400000060

[7] Koppelman, S.F., Consumer analysis of travel choice. Journal of Advanced Transportation, 14(2), pp. 133-159, 1980.

[8] Song, H. \& Li, G., Tourism demand modeling and forecasting-a review of recent research. International Journal of Hospitality Management, 22(4), pp. 435-451, 2008. 
[9] Witt, S.F. \& Witt, C.A. Forecasting tourism demand: a review of empirical research. International Journal of Forecasting, 11, pp. 447-475, 1995. doi: http://dx.doi.org/10.1016/01692070(95)00591-7

[10] Song, H. \& Wong, K.F. Tourism demand modelling: a time varying parameter approach. Tourism Management, 23, pp. 475-487, 2003. doi: http://dx.doi.org/10.1177/0047287503253908

[11] Beerlin, A. \& Martin, J.D. Tourist characteristics and the perceived image of tourist destinations: a quantitative analysis. Tourism Management, 25, pp. 623-636, 2004. doi: http://dx.doi. org/10.1016/j.tourman.2003.06.004

[12] Decrop, A. \& Snelders, D., Planning the summer vacation: an adaptable process. Annals of Tourism Research, 31(4), pp. 1008-1030, 2004. doi: http://dx.doi.org/10.1016/j.annals.2004.03.004

[13] Pina, I.P.A. \& Delfa, M.T.D., Rural tourism demand by type of accommodation. Tourism Management, 26, pp. 951-959, 2005. doi: http://dx.doi.org/10.1016/j.tourman.2004.06.013

[14] Filippini, R., Strumenti statistici per l'analisi esplorativa dei sistemi turistici, Phd thesis, University di Bologna, Dipartimento di Scienze Statistiche, 2006.

[15] Prideaux, B., The role of the transport system in destination development. Tourism Management, 21(1), pp. 53-63, 2000. doi: http://dx.doi.org/10.1016/s0261-5177(99)00079-5

[16] Prideaux, B., Possible effects of new transport technologies on the tourism industry in the 21st Century. Australasian Transport Research Forum, 18, pp. 245-258, 1993.

[17] Crampon, L. J., A New Technique to Analyze Tourist Markets. Journal of Marketing, 30(2), pp. 27-31, 1966. doi: http://dx.doi.org/10.2307/1249060

[18] Masson, S. \& Petiot, R., Can the high speed rail reinforce tourism attractiveness? The case of the high speed rail between Perpignan (France) and Barcelona (Spain). Technovation, 29(9), pp. 611-617, 2009. doi: http://dx.doi.org/10.1016/j.technovation.2009.05.013

[19] Wang, X., Huang, S., Zou, T. \& Yan, H., Effects of the high speed rail network on China's regional tourism development. Tourism Management Perspectives, 1, pp. 34-38, 2012. doi: http://dx.doi.org/10.1016/j.tmp.2011.10.001

[20] Levinson, D. M., Accessibility impacts of high-speed rail, Journal of Transport Geography, 22, pp. 288-291, 2012. doi: http://dx.doi.org/10.1016/j.jtrangeo.2012.01.029

[21] Albalate, D. \& Bel, G., High-Speed Rail: Lessons for Policy Makers from Experiences Abroad, Research Institute of Applied Economics. Working Paper 03, 34 pp., 2010.

[22] DB International GmbH, High Speed Rail as a tool for regional development (In-depth Study), 08 August 2011.

[23] SEEDA (South East England Development Agency), HST Impact Study, Final report for European Commission, available at http://www.hstimpactstudy.net/HTdocs/ Images/ mainreport 150408.pdf, 2008.

[24] Rietveld, P., Bruinsma, F., van Delft, H. \& Ubbels, B., Economic impacts of high speed trains. Experiences in Japan and France: expectations in The Netherlands. Serie Research Memoranda (de Faculteit der Economische Wetenschappen en Bedrijfskunde, 2001.

[25] Coronado, J., Garmendia, M., Moyano, A. \& Ureña, J., Assessing Spanish HSR network utility for same-day tourism. Recherche Transport et Sécurité, 29, pp.161-175, 2013.

[26] Chen, Z. \& Haynes, K. E., Tourism industry and high speed rail, is there a linkage: evidence from China's High Speed Rail development, ASRDLF 2012 conference special session on High Speed Rail, Tourism and Territories, 9th-11th July, Belfort, France, 2012. doi: http:// dx.doi.org/10.2139/ssrn.2130830

[27] Carrouet, G., Du TGV Rhin-Rhône au territoire Rhin-Rhône: réticularité, mobilité et territorialité dans un espace intermédiaire. Thèse en géographie et Aménagement, de l'Université de Bourgogne, pp. 518, 2013. 
[28] Mignerey, P., Les effets territoriaux de la grande vitesse ferroviaire en France. La Documentation Française, pp. 96, 2013.

[29] Setec organisation, Etude des effets de la réalisation d'une LGV entre Bordeaux et Narbonne sur le développement des aires urbaines d'Agen et de Montauban et sur l'aménagement des territoires traversés, pour Réseau Ferré de France, pp. 20, 2005.

[30] Seddighi, H.R. \& Theocharous, A.L., A model of tourism destination choice: a theoretical and empirical analysis. Tourism Management, 23, pp. 475-487, 2002. doi: http://dx.doi. org/10.1016/s0261-5177(02)00012-2

[31] Barros, C. P. \& Assaf, A. G., Analyzing Tourism Return Intention to an Urban Destination. Journal of Hospitality \& Tourism Research, 36, pp. 216-231, 2012.

[32] Delaplace M., Pagliara F., Perrin J. \& Mermet. S. Can High Speed Rail foster the choice of destination for tourism purpose? Procedia-Social and Behavioral Sciences, 111, pp.166-175, 2014. doi: http://dx.doi.org/10.1016/j.sbspro.2014.01.049

[33] Pagliara, F., Delaplace, M. \& Vassallo, J.M., High Speed trains and tourists: what is the link? Evidence from the French and the Spanish capitals. Proceedings of the conference Urban Transport XX - Urban Transport and the Environment in the 21st century. WIT Transactions on the Built Environment, 138, pp. 17-27, 2014. doi: http://dx.doi.org/10.2495/ut140021 
